\title{
KOINTEGRASI BURSA EFEK INDONESIA DENGAN BURSA EFEK AMERIKA SERIKAT, JEPANG, HONGKONG, DAN MALAYSIA
}

\author{
Ignatius Roni Setyawan ${ }^{*}$, Rorlen $^{2}$, Margarita Ekadjaja ${ }^{3}$ \\ ${ }^{1}$ Jurusan Manajemen, Universitas Tarumanagara Jakarta \\ Email: ign.s@fe.untar.ac.id \\ ${ }^{2}$ Jurusan Manajemen, Universitas Tarumanagara Jakarta \\ Email: rorlen@fe.untar.ac.id \\ ${ }^{3}$ Jurusan Manajemen, Universitas Tarumanagara Jakarta \\ Email:margaritae@fe.untar.ac.id \\ *penulis korespondensi
}

\begin{abstract}
ABSTRAK
Penelitian ini bertujuan untuk menganalisis kointegrasi bursa efek di negara Amerika Serikat, Jepang, Hongkong, Malaysia, dan Indonesia dari tahun 2008-2020 dengan menggunakan model Vector Autoregressive Model. Penelitian ini dilakukan pada rentang waktu selama 156 bulan, di mana data yang diamati pasca krisis global di dunia (2008-2014) dan saat kemajuan ekonomi Cina yang berdampak pada perang dagang dengan USA (20142020). Berdasarkan hasil olah data dengan menggunakan aplikasi eviews 9.0 ditemukan adanya kointegrasi antara bursa efek di negara Amerika Serikat, Jepang, Hongkong, Malaysia, dan Indonesia yang diproksikan indeks DJIA, Hang Seng, Nikkei, KLCI, dan IHSG pada tahun 2008-2020. Hasil uji Vector Error Correction Model menunjukkan tidak adanya kausalitas jangka pendek antara pergerakan indeks Dow Jones, Nikkei, Hang Seng, KLCI, dan IHSG. Hasil uji impulse response menggambarkan impact dari perubahan pada indeks Dow Jones, Hang Seng, Nikkei, dan KLCI terhadap IHSG bersifat jangka panjang untuk kembali ke posisi setara dengan perlahan (slow response). Indeks DJIA yang menguat dipercaya dapat memberikan pengaruh positif bagi saham di Indonesia. Sehingga naik atau turunnya indeks DJIA akan diikuti pula naik atau turunnya IHSG. Implikasi dari penelitian ini adalah terkointegrasinya indeks bursa efek negara di Amerika Serikat, Jepang, Hongkong, Malaysia, dan Indonesia memberikan prediksi bagi investor terhadap fluktuasi indeks saham yang akan terjadi.
\end{abstract}

Kata Kunci : Vector Autoregressive Model, kointegrasi, Vector Error Correction Model, impulse response

\begin{abstract}
This research is an empirical study regarding the cointegration of stock exchanges in US, Japan, Hongkong, Malaysia, and Indonesiafrom 2008-2020 using the Vector Autoregressive Model. This research was conducted over a period of 156 months, where data was observed after the global crisis in the world (2008-2014) and when Hongkong's economic progress had an impact on the trade war with the USA (2014-2020). Based on the results of data processing using the eviews 9.0 application, it was found that there was a cointegration between stock exchanges in the United States, Japan, Hongkong, Malaysia, and Indonesia, which were proxied by the DJIA, Hang Seng, Nikkei, KLCI, and IHSG indexes in 2008-2020. The results of the Vector Error Correction Model test show that there is no short-term causality between the movements of the Dow Jones, Nikkei, Hang Seng, KLCI, and Indonesia Composite index. The impulse response test results illustrate the long-term impact of changes in the Dow Jones, Hang Seng, Nikkei, and KLCI indices on the Indonesia Composite Index to return to an equivalent position slowly (slow response). The stronger DJIA index is believed to have a positive impact on stocks in Indonesia. So that the increase or decrease in the DJIA index will also be followed by an increase or decrease in the Indonesia Composite index. The implication of this research is the cointegration of stock exchange indexes in United States, Japan, Hongkong, Malaysia, and Indonesia can help investors to predict the fluctuation indexes.
\end{abstract}

Keywords: Vector Autoregressive Model, kointegrasi, Vector Error Correction Model, impulse response

\section{PENDAHULUAN}

Nilai dan fluktuasi indeks pada bursa suatu negara mencerminkan situasi dan fluktuasi perekonomian negara. Seiring dengan sistem perdagangan bebas dunia maka terdapat keterkaitan antar perekonomian negara-negara di dunia. Menurut Jebran (2018) perkembangan bursa efek 
menjadi acuan penetapan kebijakan ekonomi suatu negara. Negara yang mempunyai sumber daya besar akan lebih mempengaruhi perekonomian dunia. Hal ini menimbulkan istilah "negara dengan perekonomian kuat", di mana kondisi perekonomian negara tersebut sangatlah mempengaruhi kondisi perekonomian negara lainnya. Seperti bursa efek di negara Amerika Serikat yang diwakili oleh Dow Jones, Hongkong yang diwakili oleh Hang Seng dan Jepang yang diwakili oleh Nikkei akan mempengaruhi kondisi bursa efek di negara lain, seperti Malaysia yang diwakili KLCI dan Indonesia yang diwakili oleh IHSG.

Menurut Zhan (2019) indeks harga saham merupakan gambaran tren pertumbuhan ekonomi suatu negara yang sangat penting dalam perumusan kebijakan dan intervensi pasar. Indeks harga saham pada dasarnya merupakan time series non-linier dan non-stasioner yang awalnya dikembangkan oleh (Huang et al., 1998) yang menguraikan deret waktu univariat sebelum pemodelan berlangsung, untuk mendapatkan prediksi yang lebih akurat. Menurut Simbolon \& Purwanto (2018), faktor-faktor yang mempengaruhi indeks harga saham adalah tingkat bunga, tingkat inflasi, tingkat pertumbuhan, kurs valuta asing, dan indeks harga saham dari negara lain.

Indeks Harga Saham Gabungan (IHSG) di Indonesia dan indeks - indeks bursa saham negara ASEAN seperti Kuala Lumpur Composite Indeks (KLCI) cenderung mengikuti pergerakan indeks bursa saham negara maju seperti indeks saham Dow Jones Industrial Average (DJIA) yang berada di Amerika Serikat, indeks Nikkei di Jepang, dan indeks Hang Seng di Hongkong. DJIA mencerminkan kekuatan keuangan di negara Amerika Serikat karena merupakan indeks besar yang terdiri atas tiga puluh perusahaan yang sangat likuid di Amerika Serikat sehingga menjadi buruan analist, trader, dan investor. Tingginya besaran indeks DJIA menunjukkan tingginya ekonomi di negara Amerika Serikat. Hal ini menyebabkan efek penularan terhadap integrasi ekonomi negara lain (Uchoa, 2018). Hasil penelitian Kangina, et al. (2016) menunjukkan kointegrasi pasar saham antar negara yang memiliki dinamika sama, maka akan memiliki tingkat pengembalian yang diharapkan sama.

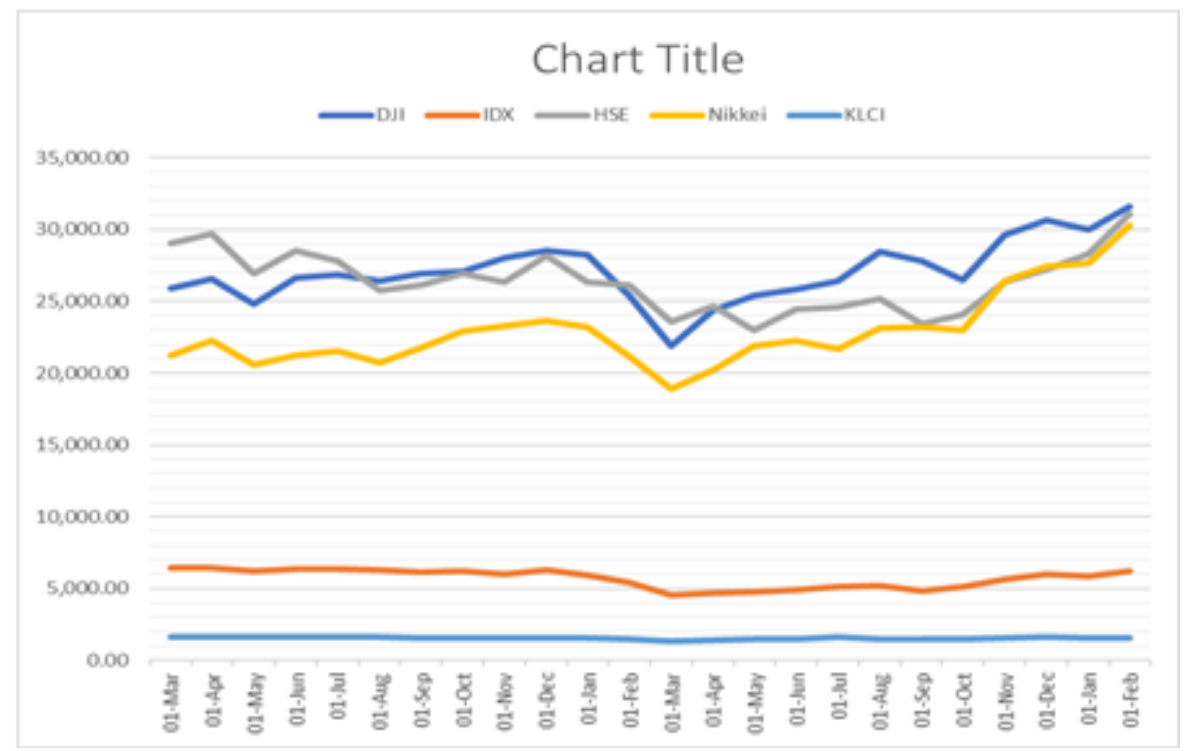

Gambar 1. Fluktuasi Indeks Bursa Saham Amerika Serikat, Jepang, Hongkong, Malaysia, dan Indonesia per Maret 2019 s/d Feb 2021

Sumber : $\underline{w w w . i n v e s t i n g . c o m ~(D i o l a h ~ P e n u l i s) ~}$

Gambar 1. menunjukkan trend fluktuasi negara maju seperti indeks bursa saham di Amerika yang diproksikan indeks Dow Jones, indeks bursa saham di Jepang yang diproksikan indeks 
Nikkei, dan indeks bursa saham di Hongkong yang diproksikan indeks Hang Seng. Fluktuasi indeks bursa saham di Malaysia yang diproksikan KLCI cenderung stabil dibandingkan dengan fluktuasi indeks bursa saham di Indonesia yang diproksikan oleh IDX. Namun pada awal terjadi pandemi Covid 19 yaitu pada bulan Maret 2020, indeks bursa saham semua negara tersebut mengalami penurunan.

Irmalis \& Muzakir (2019) melakukan analisis terhadap Bursa Efek Indonesia, Malaysia dan Singapura dan dalam pengujian multivariate tidak ditemukan adanya kointegrasi, namun dalam analisis bivariat Bursa Malaysia dan Bursa Singapura menunjukkan adanya kointegrasi. Hasil penelitian Santoso \& Setyawan (2016) menemukan adanya kointegrasi harga pasar saham Asia dengan Jakarta Composite Indeks (JCI) dan yang paling mewakili adalah indeks Hang Seng dan indeks STI (Singapore).

Analisis kointegrasi diperkenalkan oleh Engle \& Granger (1987), yang mengukur diversifikasi berdasarkan harga suatu aset dalam jangka panjang. Clare, et al. (1995) menganalisis kointegrasi obligasi internasional di AS, Inggris, Jerman dan Jepang, dengan metode Johansen dan pendekatan univariat (berpasangan), tidak ditemukan kointegrasi antar obligasi. Namun, uji kointegrasi menggunakan uji Johanden (1991) lebih umum digunakan. Kemudian, Mills \& Mills (1991) menggunakan data imbal hasil obligasi internasional yang sama tetapi pendekatan yang berbeda (pendekatan multivariate) untuk menguji kointegrasi obligasi, hasilnya sama (tidak terintegrasi).

Teori keterkaitan antar variabel dalam penelitian ini didasarkan pada hasil penelitian Engle \& Granger (1987), Johansen (1991) yang menemukan bahwa untuk menentukan keberadaan kesetaraan jangka panjang antara variabel yang dipilih melalui analisa kointegritas membangun langkah untuk pendekatan yang disukai untuk menganalisa hubungan antara variabel ekonomi dan pasar modal. Sekumpulan variabel dalam waktu tertentu akan berkointegrasi jika variabel tersebut berintegrasi searah dan kombinasi linier antar variabel tersebut tetap. Kombinasi linier seperti itu menunjukkan keberadaan hubungan jangka panjang antar variabel. Keunggulan dari analisa kointegrasi adalah melalui pembentukan model vector error correction model, dynamic comovement antar variabel dan proses penyesuaian menuju kesetaraan jangka panjang dapat diuji.

Hasil penelitian Robiyanto (2018) menunjukkan adanya comovement antara pasar modal negara ASEAN (Indonesia, Malaysia, Singapura dan Thailand) sejak Januari 1977 sampai Desember 2013 dan berkurangnya integrasi antar pasar modal ASEAN akibat krisis keuangan global tahun 2008. Penelitian ini merupakan studi empiris lanjutan dari penelitian Robiyanto (2018) mengenai kointegrasi bursa saham di negara Amerika, Jepang, Hongkong, Malaysia dan Indonesia dari tahun 2008-2020 dengan menggunakan model Vector Autoregressive Model (VAR) dan kointegrasi multivariat.

Manfaat penelitian ini memberikan kontribusi penting bagi investor dalam meminimalkan risiko melalui diversifikasi investasi juga penting bagi pembuat kebijakan dalam merancang strategi makroekonomi yang bijaksana dalam mempromosikan pasar saham. Egger \& Zhu (2019), mengamati respons pasar saham di seluruh dunia dalam konteks peristiwa perang dagang antara AS-China yang memiliki variasi berbeda-beda terkait level kointegrasi atau level manfaat diversifikasi internasional di setiap bursa. Dengan begitu penelitian ini akan menganalisis dampak keterkaitan dinamis antara indeks bursa saham di negara maju dan ASEAN dalam 
konteks tidak langsung dari perang dagang AS-China melalui identifikasi rumusan masalah yakni:

1. Apakah bursa efek negara di negara Malaysia dan Indonesia memiliki keterkaitan dinamis dengan bursa efek di negara Amerika Serikat, Jepang, dan Hongkong menggunakan model VAR dan kointegrasi ?

2. Di antara bursa efek negara Amerika Serikat, Jepang, Hongkong, dan Malaysia bursa efek manakah yang paling mempengaruhi bursa efek Indonesia?

\section{Perumusan Hipotesis}

Teori portofolio modern menyepakati bahwa diversifikasi dapat mereduksi adanya risiko portofolio karena aset yang terkait tidak dimiliki secara sempurna; akan tetapi, diharapkan bahwa aset internasional dari diversifikasi dapat menawarkan keuntungan yang lebih besar bagi investor karena kurangnya hubungan langsung dengan harga mereka dan juga terdapatnya pengaruh faktor fundamental ekonomi yang tidak sama.

Lanouar, et al (2015) menemukan peluang diversifikasi pada investor lokal yang menggunakan indeks Syariah dan konvensional. Hasil penelitian Lanouar, et al (2015) menemukan bahwa indeks konvensional dan syariah di London dan Amerika tidak terintegrasi dan di negara Amerika hanya indeks SRI dan indeks Syariah yang tidak terintegrasi. Menurut Arif, et al. (2017), kemungkinan diversifikasi internasional di antara ekonomi BRICS-P dapat membantu investor dalam memaksimalkan utilitas mereka dengan mendapatkan keuntungan yang lebih tinggi dengan tingkat risiko tertentu. Untuk menilai manfaat dari diversifikasi dan untuk mengeksplorasi dinamika jangka panjang dan jangka pendek dari pasar saham terpilih, studi ini menggunakan pendekatan Auto Regressive Distributive Lag (ARDL).

Balaji, et al., (2018) berpendapat bahwa pemilihan umum pemimpin tertinggi di suatu negara mempengaruhi fluktuasi pasar modal negara tersebut. Dalam penelitian yang dilakukan Halim \& Marcories (2011) bursa efek di negara Hongkong mendominasi Bursa Efek Indonesia sehingga fluktuasi bursa efek di Hongkong akan berpengaruh terhadap Bursa Efek Indonesia.

Penelitian Suganda \& Hariyono (2018) menemukan hasil terintegrasinya bursa efek antar negara di ASEAN-5 pasca pemilihan Donald Trump. Santoso \& Setyawan (2016), menemukan adanya kointegrasi harga pasar saham Asia dengan Jakarta Composite Index (JCI) dan yang paling mewakili adalah indeks Hang Seng dan STI. Menuru Robiyanto (2017), terdapat comovement pada Pasar Modal ASEAN di mana dari lima bursa efek ASEAN yang meliputi negara Malaysia, Singapura, Thailand, dan Indonesia, Filipina, yang terintegrasi hanya BEI, JKCI, SET, dan SSE. Hasil penelitian Ikrima \& Muharam (2015) menemukan bahwa saat krisis di negara Yunani terdapat kointegrasi antara pasar modal di negara Amerika Serikat, Malaysia, Indonesia, dan Eropa. Namun tidak berpengaruh signifikan terhadap harga pasar saham Syariah di Amerika Serikat, Malysia, Indonesia, dan Eropa. Natsir, et al. (2019) melakukan pengujian kausalitas melalui Uji Granger menunjukkan adanya keterkaitan antara IHSG dengan nilai Rupiah/US\$ dan indeks Dow Jones Industrial berpengaruh signifikan satu arah terhadap pergerakan IHSG dan nilai tukar Rupiah/US\$.

Dari beberapa penelitian terdahulu, hipotesis yang digunakan dalam penelitian ini sebagai berikut

Ho: Tidak terdapat kointegrasi antara indeks Dow Jones, indeks Nikkei, indeks Hang Seng, indeks KLCI dengan IHSG.

H1: Terdapat kointegrasi antara indeks Dow Jones, indeks Nikkei, indeks Hang Seng, indeks 


\section{KLCI dengan IHSG.}

\section{METODE PENELITIAN}

Sekaran \& Bougie (2016) menyatakan bahwa terdapat dua jenis desain penelitian, yaitu desain penelitian deskriptif dan desain penelitian kausal. Dalam penelitian ini, peneliti menggunakan desain penelitian kausal. Bentuk data yang digunakan dalam penelitian ini adalah data time series atau data runtun waktu. Sesuai dengan metode dan desain penelitian maka peneliti ingin memberikan gambaran hubungan-hubungan yang terjadi antara variabel independen dan variabel dependen, dan juga menjawab hipotesis penelitian yang telah disusun.

Sampel penelitian berupa nilai indeks saham di negara Amerika Serikat, Jepang, Hongkong,Malaysia, dan Indonesia. Data sekunder merupakan data bulanan harga perdagangan indeks Dow Jones, Nikkei, Hang Seng, KLCI, dan IHSG dari tahun 2008-2020. Sumber data penelitian diperoleh dari website keuangan (www.investing.com).

Hasil penelitian diatas akan diuji menggunakan uji Engle-Granger sehingga diperoleh standar kausalitas untuk memberikan bukti empiris yang komprehensif mengenai kointegrasi antar variabel penelitian. Penelitian ini dilakukan pada rentang waktu selama 156 bulan, di mana data yang diamati pasca krisis global di dunia (tahun 2008-2014) dan saat kemajuan ekonomi Cina yang berdampak pada perang dagang dengan Amerika Serikat (tahun 2014-2020)

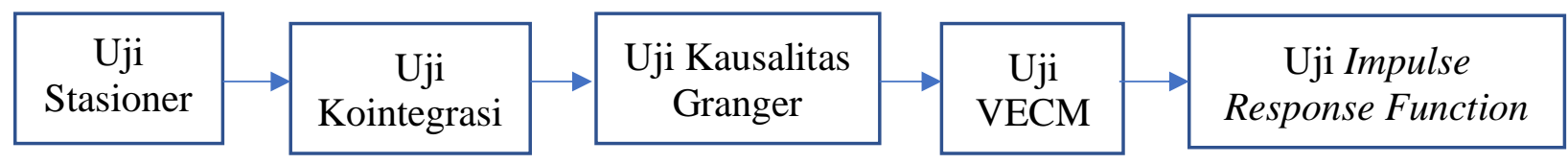

Gambar 2. Tahapan Dalam Penelitian

Sumber : Penulis (2021)

Berdasarkan Gambar 2, beberapa langkah analisis empiris dalam penelitian dilakukan : (1) Uji stasioner untuk setiap indeks dilakukan dengan menggunakan Augmented Dickey-Fuller (ADF). (2) Uji kointegrasi antara bursa efek pasar saham di Amerika Serikat, Jepang, Hongkong, Malaysia dan Indonesia. Dalam pengujian kointegrasi antara bursa efek di Amerika Serikat, Jepang, Hongkong, Malaysia, dan Indonesia, penelitian ini menggunakan Johansen dalam kerangka Vector Autoregressive (VAR). Kehadiran kointegrasi di antara pasar-pasar ini dinilai dengan menggunakan tes statistik Johansen. (3) Uji kausalitas bivariat antara bursa efek di Amerika Serikat, Jepang, Hongkong, Malaysia, dan Indonesia dengan menggunakan uji kausalitas Granger. (4) Uji kausalitas jangka pendek di antara indeks di Amerika Serikat, Jepang, Hongkong, dan Indonesia dalam kerangka multivariat menggunakan Vector Error Correction Model (VECM). Di mana uji VECM digunakan ketika uji Johansen menunjukkan satu atau lebih kointegrasi persamaan. (5) Uji kausalitas jangka panjang di antara indeks di Amerika Serikat, Jepang, Hongkong, Malaysia, dan Indonesia dalam kerangka bivariat menggunakan Impulse Response Function.

Penelitian ini menggunakan pendekatan kointegrasi Johansen, dimulai dengan variabel stokastik vector $\mathrm{X}_{\mathrm{t}}$ sebagai VAR (Vector Autoregression). Persamaan penelitian model VAR sebagai berikut : $\mathbf{X}_{\mathrm{t}}=\boldsymbol{\beta} \mathbf{X}_{\mathrm{t}-1}+\boldsymbol{\beta}_{1} \mathbf{X}_{\mathrm{t}-2} \ldots \ldots+\boldsymbol{\beta}_{\mathrm{p}} \mathbf{X}_{\mathrm{t}-\mathrm{p}}+\mathbf{c}+\mathbf{e}$

Dimana : $\mathrm{X}_{\mathrm{t}}=\left[\mathrm{DJI}_{\mathrm{t}}\right.$, Nikkeit , Hang Seng $\mathrm{HLCI}_{\mathrm{t}}$, IHSG $\mathrm{KH}_{\mathrm{t}}$ merupakan vector $(5 \mathrm{x} 1)$ meliputi tingkat indeks harga saham lima negara, yaitu tiga indeks harga saham di negara Amerika Serikat, Jepang, dan Hongkong, Malaysia dan Indonesia). 
Tabel 1. Variabel Operasional

Sumber: www.investopedia.com

\begin{tabular}{|c|c|c|c|c|c|}
\hline No & Negara & Indeks & Simbol & Metode Pembentukan & Base Year \\
\hline 1 & Indonesia & $\begin{array}{c}\text { Indeks Harga Saham } \\
\text { Gabungan }\end{array}$ & IHSG & $\begin{array}{c}\text { Market Capitalization }= \\
\left(\sum \text { saham tercatat } \mathrm{x} \text { harga }\right. \\
\text { terakhir }):\left(\sum \text { saham perdana } \mathrm{x}\right. \\
\text { harga perdana })\end{array}$ & 1982 \\
\hline 2 & $\begin{array}{l}\text { Amerika } \\
\text { Serikat }\end{array}$ & $\begin{array}{c}\text { Dow Jones Industrial } \\
\text { Average }\end{array}$ & DJIA & $\begin{array}{c}\sum \text { (Component stock prices) } / \\
\text { Dow divisor } \\
\end{array}$ & 1896 \\
\hline 3 & Jepang & Nikkei & NIKE & 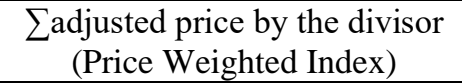 & 1970 \\
\hline 4 & Cina & Hang Seng & HSNG & $\begin{array}{l}\text { Market Capitalization Weighted } \\
\text { Index }\end{array}$ & 1969 \\
\hline 5 & Malaysia & $\begin{array}{l}\text { Kuala Lumpur } \\
\text { Composite Index }\end{array}$ & KLCI & $\begin{array}{c}\text { Market Capitalization }= \\
\left(\sum \text { saham tercatat } \mathrm{x} \text { harga }\right. \\
\text { terakhir }):\left(\sum \text { saham perdana } \mathrm{x}\right. \\
\text { harga perdana })\end{array}$ & 1977 \\
\hline
\end{tabular}

Tabel 1. Variabel Operasional mendeskripsikan ukuran dari masing-masing variabel penelitian yang meliputi IHSG, indeks Dow Jones, Nikkei, Hang Seng, dan KLCI.

\section{HASIL DAN PEMBAHASAN}

\subsection{Uji Stationer dan Kointegrasi}

Dalam melakukan uji stasioner data, dilakukan uji root untuk memastikan stasioneritas variabel untuk menghindari regresi palsu. Pengujian stasioner data dapat terlihat pada hasil uji root test yang menunjukkan data tidak stasioner pada tingkat level, tetapi stasioner pada level first difference.

Tabel 2. Hasil Root Test First Difference

Sumber : Hasil Olah Data Penulis (2021)

\begin{tabular}{|c|c|c|c|c|}
\hline \multicolumn{5}{|c|}{$\begin{array}{l}\text { Group unit root test : Summary } \\
\text { Series : IHSG, HSNG, DJIA, KLCI, NIKE } \\
\text { Sampel : 2008M01 2020M12 } \\
\text { Automatic lag length selection based on SIC: } 0 \text { to } 1\end{array}$} \\
\hline Method & Statistic & Prob** & Cross-sections & Obs \\
\hline $\begin{array}{l}\text { Null:Unit root } \\
\text { Levin, Lin } * \text { Chu t* }\end{array}$ & -28.1744 & 0.0000 & 5 & 769 \\
\hline \multicolumn{5}{|c|}{ Null:Unit root (assumes individual unit root process) } \\
\hline $\begin{array}{l}\text { lm,Pesaran and Shin } \\
\text { W-stat }\end{array}$ & -24.8252 & 0.0000 & 5 & 769 \\
\hline ADF-Fisher Chi-square & 379.653 & 0.0000 & 5 & 769 \\
\hline PP-Fisher Chi-square & 399.723 & 0.0000 & 5 & 770 \\
\hline
\end{tabular}

Berdasarkan Tabel 2. Hasil Root Test First Difference, besaran probabilita semua variabel adalah lebih kecil dari tingkat signifikansi yaitu prob 0,0000, sehingga data penelitian stasioner pada level first difference. Sebelum dilakukan uji kointegrasi dilakukan maka perlu dilakukan pengujian panjang lag optimum dan uji stabilitas data. Dalam penelitian ini diperoleh lag optimum kriterianya adalah 1. 
Tabel 3. Hasil Uji Stabilitas

Sumber: Hasil Olah Data Penulis (2021)

\begin{tabular}{|c|c|}
\hline $\begin{array}{l}\text { Roots of Characteristic } \\
\text { Endogenous variables: } \\
\text { Exogenous variables: } \mathrm{C} \\
\text { Lag specification : } 11\end{array}$ & DJIA) D(KLCI) D(NIKE) \\
\hline Root & Modulus \\
\hline 0.205461 & 0.205461 \\
\hline-0.190314 & 0.190314 \\
\hline$-0.061943-0.107402 \mathrm{i}$ & 0.123985 \\
\hline$-0.061943+0.107402 i$ & 0.123985 \\
\hline-0.005464 & 0.005464 \\
\hline
\end{tabular}

Berdasarkan Tabel 3. Hasil Uji Stabilitas terlihat nilai semua modulus adalah dibawah 1, sehingga dapat disimpulkan bahwa data penelitian adalah stabil.

Tabel 4. Johansen Cointegration Test

Sumber : Hasil Olah Data Penulis (2021)

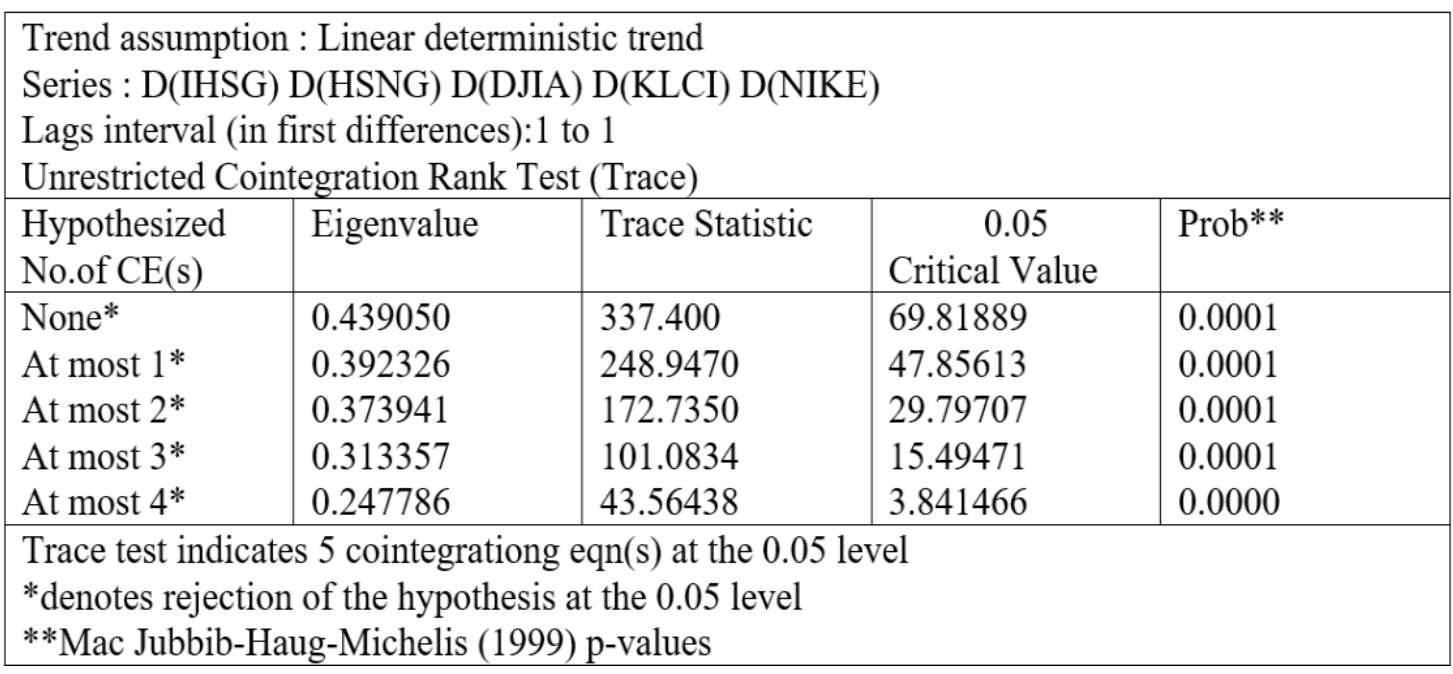

Berdasarkan Tabel 4. Johansen Cointegration Test teridentifikasi adanya kointegrasi antar indeks DJIA, Hang Seng, Nikkei, KLCI, dan IHSG pada tahun 2008-2020, hal ini dibuktikan nilai Trace Statistic > Critical Value dengan critical level sebesar 0.05.

\subsection{Uji Kausalitas Granger}

Setelah memvalidasi keberadaan kointegrasi, untuk menemukan arah kausalitas bivariat antara bursa efek di negara Amerika Serikat, Jepang, Hongkong, dan Malaysia dengan bursa efek di negara Indonesia.Hasilnya dapat dilihat pada tabel 5. 
Tabel 5. Granger Causality Tests

\begin{tabular}{|l|c|c|c|c|}
\hline $\begin{array}{l}\text { Pairwise Granger Causality Tests } \\
\text { Lags: } 1\end{array}$ & $\begin{array}{c}\text { Hasil } \\
\text { Hipotesis }\end{array}$ \\
\hline Null Hypothesis: & Obs & F-Statistic & Prob. & \\
\hline HSNG does not Granger Cause IHSG & 155 & 3.72830 & $0.0554^{* *}$ & Diterima \\
IHSG does not Granger Cause HSNG & & 9.82434 & $0.0021^{*}$ & Diterima \\
\hline DJIA does not Granger Cause IHSG & 155 & 0.03885 & 0.8440 & Ditolak \\
IHSG does not Granger Cause DJIA & & 1.26713 & 0.2621 & Ditolak \\
\hline KLCI does not Granger Cause IHSG & 155 & 1.02016 & 0.3141 & Ditolak \\
IHSG does not Granger Cause KLCI & & $5.8 \mathrm{E}-05$ & 0.9939 & Ditolak \\
\hline NIKE does not Granger Cause IHSG & 155 & 0.44296 & 0.5067 & Ditolak \\
IHSG does not Granger Cause NIKE & & 3.68754 & $0.0567^{* *}$ & Diterima \\
\hline DJIA does not Granger Cause HSNG & 155 & 4.36631 & $0.0383^{*}$ & Diterima \\
HSNG does not Granger Cause DJIA & & 0.56840 & 0.4521 & Ditolak \\
\hline KLCI does not Granger Cause HSNG & 155 & 4.43198 & $0.0369^{*}$ & Diterima \\
HSNG does not Granger Cause KLCI & & 5.49119 & $0.0204^{*}$ & Diterima \\
\hline NIKE does not Granger Cause HSNG & 155 & 1.94822 & 0.1648 & Ditolak \\
HSNG does not Granger Cause NIKE & & 0.12074 & 0.7287 & Ditolak \\
\hline KLCI does not Granger Cause DJIA & 155 & 0.57710 & 0.4486 & Ditolak \\
DJIA does not Granger Cause KLCI & & 0.66674 & 0.4155 & Ditolak \\
\hline NIKE does not Granger Cause DJIA & 155 & 0.23192 & 0.6308 & Ditolak \\
DJIA does not Granger Cause NIKE & & 4.03359 & $0.0464^{*}$ & Diterima \\
\hline NIKE does not Granger Cause KLCI & 155 & 1.71461 & 0.1924 & Ditolak \\
KLCI does not Granger Cause NIKE & & 1.76876 & 0.1855 & Ditolak \\
\hline
\end{tabular}

* Signifikansi level 0,05

Sumber : Hasil Olah Data Penulis (2021)

** Signifikansi level 0,1

Berdasarkan Tabel 5. Granger Causality Tests, dengan tingkat signifikansi level 0.05, diperoleh hasil bahwa tidak terjadi integrasi antara indeks Hang Seng dan IHSG, dimana indeks IHSG tidak mempengaruhi indeks Hang Seng dan juga sebaliknya. Hal ini bertentangan dengan Santoso \& Setyawan (2016), dimana hasil penelitian menemukan adanya kointegrasi harga pasar saham Asia dengan Jakarta Composite Index (JCI) dan yang paling mewakili adalah indeks Hang Seng dan STI.

Kointegrasi bivariat terjadi pada indeks DJIA terhadap IHSG, indeks KLCI terhadap IHSG, indeks Nikkei terhadap indeks Han Seng, indeks DJIA terhadap indeks KLCI, dan indeks Nikkei terhadap indeks KLCI pada tahun 2008-2020 dapat dilihat dari besarnya probabilita yang lebih besar dari 0.05 .

Hasil penelitian menunjukkan adanya hubungan yang saling mempengaruhi antar bursa efek di negara Amerika Serikat, Jepang, Hongkong, Malaysia, dan Indonesia. Hal ini sejalan dengan hasil penelitian Ikrima \& Muharam (2015) dimana hasil penelitian menemukan bahwa saat krisis di negara Yunani terdapat kointegrasi antara pasar modal di negara Amerika Serikat, Malysia, Indonesia, dan Eropa. Namun tidak berpengaruh signifikan terhadap harga pasar saham Syariah di Amerika Serikat, Malysia, Indonesia, dan Eropa.

Kointegrasi juga terjadi pada indeks Nikkei terhadap indeks IHSG dan memiliki hubungan kausalitas searah, dimana pergerakan indeks IHSG tidak mempengaruhi pergerakan indeks Nikkei. Hal ini menunjukkan bahwa IHSG terpengaruh dari indeks harga saham negara maju namun juga pengaruh kondisi dalam negeri yang tidak memberikan dampak sebaliknya pada 
indeks harga saham di negara maju. Demikian integrasi antara indeks Nikkei terhadap Dow Jones adalah searah dan indeks Dow Jones tidak berpengaruh signifikan terhadap pergerakan nilai indeks Nikkei.

Hasil integrasi antara DJIA dengan HSNG memiliki hubungan searah terlihat pada salah satu besarnya probabilita integrasi antara indeks Dow Jones dengan Hang Seng lebih kecil dari tingkat signifikansi level. Sementara integrasi antara indeks KLCI dengan indeks Hang Seng bersifat bivariat dan signifikan, yang artinya tidak ada hubungan kausalitas antara pergerakan indeks Hang Seng dengan pergerakan indeks KLCI dan sebaliknya.

IHSG dan indeks - indeks bursa saham negara ASEAN seperti Kuala Lumpur Composite Index (KLCI) cenderung mengikuti pergerakan indeks bursa saham negara maju seperti indeks Dow Jones yang berada di Amerika Serikat, Indeks Nikkei di Jepang, dan Indeks Hang Seng di Hongkong. Bukti yang menunjukkan pergerakan ini adalah salah satu kejadian di Amerika Serikat pada tahun 2007 - 2010 dimana adanya krisis keuangan global yang diakibatkan oleh subprime mortgage yang mengakibatkan banyaknya kebangkrutan institusi keuangan besar seperti Lehman Brothers, Fannie Mae, dan Freddie Mac. Hal ini menyebabkan efek penularan terhadap integrasi ekonomi negara lain (Uchoa, 2018).

Demikian pula saat kemajuan ekonomi Cina yang berdampak pada perang dagang dengan Amerika Serikat memberikan pengaruh fluktuasi indeks harga pasar saham di seluruh dunia pada tahun 2014-2020. Dampak tersebut juga mempengaruhi pertumbuhan ekonomi di Indonesia karena Amerika Serikat merupakan tujuan ekspor utama dari produk-produk Indonesia. Penguatan kondisi keuangan di Amerika Serikat berpengaruh positif terhadap pergerakan harga indeks DJIA dan dapat memberikan pengaruh positif terhadap pergerakan harga IHSG. Argumen ini sesuai Christa \& Pratomo (2015) yang memperlihatkan bahwa indeks DJIA berpengaruh secara signifikan terhadap IHSG.

Hasil penelitian mengindikasi adanya kointegrasi antar bursa efek akan berdampak jangka panjang terhadap kinerja antar bursa efek dan juga dapat memberikan dampak sistemik dari terpuruknya bursa Dow Jones, Nikkei, Hang Seng dan KLCI terhadap IHSG. Namun selain itu juga dampak memberikan dampak positif bagi kinerja bursa efek antar negara di Amerika Serikat, Jepang, Hongkong, Malaysia, dan Indonesia.

\subsection{Uji VECM}

Tabel 6. Hasil Estimasi VECM

Sumber : Hasil Olah Data Penulis (2021)

\begin{tabular}{|c|c|c|c|c|c|}
\hline \multicolumn{6}{|c|}{$\begin{array}{l}\text { Vector Error Correction Estimates } \\
\text { Sample (adjusted): } 2008 \mathrm{M} 042020 \mathrm{M} 12 \\
\text { Included observations: } 153 \text { after adjustments }\end{array}$} \\
\hline $\begin{array}{c}\text { Error } \\
\text { Correction }\end{array}$ & D(IHSG) & $\mathrm{D}$ (HSNG) & D(DJIA) & $\mathrm{D}(\mathrm{KLCI})$ & $\mathrm{D}(\mathrm{NIKE})$ \\
\hline CointEq $^{1}$ & 0.034195 & 0.306672 & 0.037083 & 0.012878 & 0.081091 \\
\hline t-stat & [2.17952] & [3.07901] & {$[0.58307]$} & [3.52393] & [1.16161] \\
\hline $\mathrm{D}(\operatorname{IHSG}(-1))$ & 0.053674 & 0.238634 & 0.303046 & 0.017160 & -0.450739 \\
\hline t-stat & [0.49019] & [0.34329] & [0.68273] & [0.67284] & {$[-0.92515$} \\
\hline $\mathrm{D}(\mathrm{HSNG}(-1))$ & 0.007080 & -0.005166 & 0.000132 & 0.001955 & 0.111848 \\
\hline t-stat & [0.41370] & {$[-0.04755]$} & {$[0.00191]$} & [0.49034] & [1.46872] \\
\hline D(DJIA(-1)) & 0.015413 & -0.304640 & -0.120682 & 0.004065 & 0.014288 \\
\hline t-stat & [0.46301] & {$[-1.44151]$} & {$[-0.89429]$} & [0.52432] & {$[0.09646]$} \\
\hline $\mathrm{D}(\mathrm{KLCI}(-1))$ & 0.668214 & 4.703611 & 2.990086 & -0.028268 & 1.962229 \\
\hline t-stat & [1.50901] & [1.67318] & {$[1.66572]$} & {$[-0.27407]$} & [0.99589] \\
\hline $\mathrm{D}(\mathrm{NIKE}(-1))$ & 0.025284 & 0.064600 & 0.001493 & 0.002595 & -0.006149 \\
\hline t-stat & [0.88337] & {$[0.35552]$} & {$[0.01287]$} & [0.38932] & {$[-0.04828$} \\
\hline $\mathrm{C}$ & 18.83065 & 37.32401 & 123.1026 & 0.750279 & 93.28843 \\
\hline t-stat & [1.15340] & {$[0.36011]$} & [1.86003] & [0.19730] & [1.28418] \\
\hline R-squared & 0.089185 & 0.110181 & 0.042242 & 0.099851 & 0.041014 \\
\hline Adj. R-squared & 0.052009 & 0.073862 & 0.003150 & 0.063110 & 0.001872 \\
\hline \multicolumn{6}{|c|}{$\mathrm{t}$-table $=1.976013$} \\
\hline
\end{tabular}


Pada Tabel 6 ditunjukkan hasil estimasi VECM. Hasilnya menggambarkan tidak adanya kausalitas jangka pendek antara pergerakan indeks DowJones, indeks Nikkei, indeks Hang Seng, indeks KLCI, dan IHSG, tercermin t-statistik variabel IHSG, HSNG, DJIA, KLCI, dan NIKE lebih kecil daripada t-table. Hal ini ditunjukkan dari besarnya R-squared dalam simulasi untuk mengetahui hubungan antar variabel. Hubungan variabel IHSG terhadap indeks Dow Jones, indeks Hang Seng, indeks Nikkei, indeks KLCI hanya sebesar 8,92\% dan sisanya dipengaruhi oleh variabel lain yang tidak tercangkup dalam penelitian.

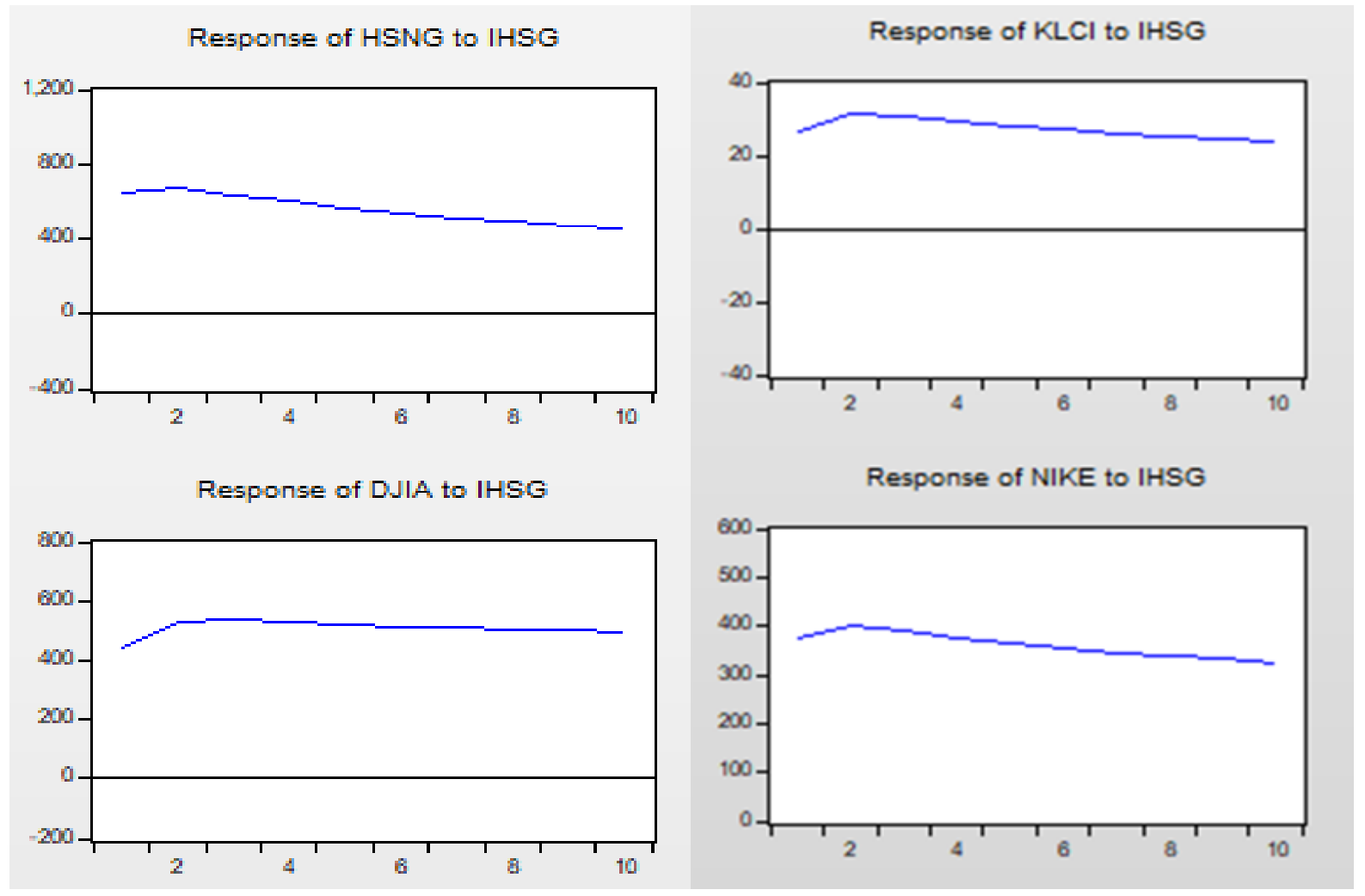

Gambar 3. Impulse Response terhadap IHSG

Sumber : Hasil Olah Data Penulis (2021)

Fungsi Impulse Response mengamati pengaruh perubahan standar deviasi terhadap nilai variabel indeks bursa berdasarkan periode sekarang dan waktu yang akan datang. Gambar 3. Impulse Response menunjukkan hasil pengamatan selama 13 tahun dari fluktuasi yang terjadi pada bursa efek di negara Amerika Serikat, Jepang, Hongkong, dan Malaysia terhadap bursa efek di negara Indonesia.

Sumbu vertikal menunjukkan besaran penyimpangan yang mengukur seberapa besar shock response antar variabel. Sumbu horizontal menunjukkan lamanya periode (dalam tahun) dari response yang diberikan terhadap shock. Dari hasil uji impulse response, dapat dilihat bahwa response yang diberikan diatas sumbu horizontal sehingga dapat disimpulkan bahwa shock response memberikan pengaruh yang positif. 
Response dalam 10 tahun indeks bursa saham di Amerika Serikat, Jepang, Hongkong, Malaysia adalah stabil terhadap pergerakan indeks bursa saham di Indonesia. Impact dari perubahan pada indeks saham negara lain terhadap IHSG bersifat jangka panjang untuk kembali ke posisi setara karena adanya kerjasama antar negara di bidang perdagangan, sosial budaya, dan lainnya yang berjalan dengan perlahan (slow response) karena dipicu oleh kondisi perekonomian dunia yang lesu dan lambatnya pergerakan roda perekonomian.

\section{KESIMPULAN DAN SARAN}

Berdasarkan hasil pengujian data menggunakan aplikasi eviews 9.0, ditemukan adanya kointegrasi antara bursa efek di negara Amerika Serikat, Jepang, Hongkong, Malaysia, dan Indonesia yang diproksikan indeks DJIA, Hang Seng, Nikkei, KLCI, dan IHSG pada tahun 2008-2020. Hasil uji kointegrasi menunjukkan tidak terjadi integrasi antara indeks Hang Seng dan IHSG, dimana indeks IHSG tidak mempengaruhi indeks Hang Seng dan juga sebaliknya. Kointegrasi bivariat terjadi pada indeks DJIA terhadap IHSG, indeks KLCI terhadap IHSG, indeks Nikkei terhadap indeks Han Seng, indeks DJIA terhadap indeks KLCI, dan indeks Nikkei terhadap KLCI Kointegrasi juga terjadi pada indeks Nikkei terhadap IHSG dan memiliki hubungan kausalitas searah, dimana pergerakan indeks IHSG tidak mempengaruhi pergerakan indeks Nikkei. Demikian integrasi antara indeks Nikkei terhadap Dow Jones adalah searah dan indeks Dow Jones tidak berpengaruh signifikan terhadap pergerakan nilai indeks Nikkei. Hasil integrasi antara DJIA dengan HSNG memiliki hubungan searah terlihat pada salah satu besarnya probabilita integrasi antara indeks Dow Jones dengan Hang Seng lebih kecil dari tingkat signifikansi level. Sementara integrasi antara indeks KLCI dengan indeks HanSeng bersifat bivariat dan signifikan, yang artinya tidak ada hubungan kausalitas antara pergerakan indeks Hang Seng dengan pergerakan indeks KLCI dan sebaliknya.

Hasil estimasi Vector Error Correction Model (VECM) menggambarkan tidak adanya kausalitas jangka pendek antara pergerakan indeks Dow Jones, indeks Nikkei, indeks Hang Seng, indeks KLCI, dan IHSG. Hasil uji impulse response, dapat dilihat bahwa impact dari perubahan pada indeks saham negara lain terhadap IHSG bersifat jangka panjang untuk kembali ke posisi setara dengan perlahan (slow response)

Implikasi dari penelitian ini adalah terkointegrasinya indeks bursa efek negara di Amerika Serikat, Jepang, Hongkong, Malaysia, dan Indonesia memberikan prediksi bagi investor terhadap fluktuasi yang akan terjadi. Sebagai saran, investor juga perlu mengamati faktor ekonomi ekonomi makro lainnya seperti nilai tukar USD, harga minyak, harga emas dan suku bunga Federal Reserve Bank USA. Hal ini didasari dari pendapat Ibrahimi, et.al. (1995) dalam studi Yossinilayanti (2006) bahwa ada bukti nyata hubungan antara faktor internasional tersebut terhadap return maupun transaksi investor asing dan domestik di BEJ pada pra krisis: April 1995- Juli 1997; Puncak Krisis: Agustus 1997 - April 1999), Pasca Krisis I: Mei 1999 - April 2001 dan Pasca Krisis II: Mei 2001 - Januari 2006. Intinya adalah berlakunya model IAPT (International Arbitrage Pricing Theory) maupun ICAPM (International Capital Asset Pricing Model) sebagai salah satu varian penting pendekatan penelitian kointegrasi.

\section{Ucapan Terima Kasih}

Terima kasih kepada LPPM UNTAR yang telah mendanai kegiatan penelitian sesuai dengan Surat Perjanjian Pelaksanaan Penelitian Periode 1 Tahun Anggaran 2021 Nomor : 541-IntKLPPM/UNTAR/IV/2021 dan FEB UNTAR yang telah membantu kegiatan administrasi penelitian. Terima kasih kepada Valentino Chandrawinata dan Jefferson Indra Gotama selaku 
mahasiswa Program Studi S-1 Manajemen FEB UNTAR yang telah ikut serta membantu di dalam pelaksanaan kegiatan penelitian.

\section{REFERENSI}

Arif, Imtiaz, Ather Iqbal, Syed Farasar Ali, Amna Sohail Rawat.(2017).International stock market diversification cointegration analysis. Journal of Management Sciences, 4(2), 269285.

Balaji, C.,Kusuma, G. D. V, \& Kumar, B. R. (2018). Impact of general elections on stock markets in india. Open Journal of Economics and Commerce, 1(2), 1-7.

Christa, R., \& Pratomo, W. A. (2015). Analisis pengaruh indeks harga saham di bursa global terhadap indeks harga saham gabungan di BEI. Jurnal Ekonomi dan Keuangan, $1(8)$.

Clare,A.D.,Maras, M \&Thomas,S.H.(1995).The integration and efficiency of international bond market. Journal of Business Finance, 22(2), 313-322.

Egger, Peter H \& Zhu Jiaqing. (2019). The US-chinese trade war: an event study of stock-market responses. Suomen Pankki Bank of Finland. Diunduh pada 20 September 2020, dari https://www.economicpolicy.org/wp- content/uploads/2019/09/998 US-Hongkong-TradeWar.pdf.

Engle, R \& Granger, C. (1987) Co-integration and error correction: representation, estimation, and testing. Journal Econometrica, 55(2), 251-76.

Halim, J. \& Marcories.(2011). Analisis pengaruh pergerakan bursa internasional terhadap pergerakan bursa indonesia. Journal of Applied Finance and Accounting 3(2) 181-203

Huang, N. E., Shen, Z., Long, S. R., Wu, M. C., Snin, H. H., Zheng, Q.,Liu, H. H. (1998). “The empirical mode decomposition and the hubert spectrum for nonlinear and non-stationary time series analysis". Proceedings of the Royal Society A: Mathematical, Physical and Engineering Sciences, 454, 903-995.https://doi.org/10.1098/rspa.1998.0193

Ikrima, T. N., \& Muharam, H. (2015). Co-integration dan contagion effect antara pasar saham syariah di indonesia, malaysia, eropa, dan amerika saat terjadinya krisis yunani. Jurnal Dinamika Manajemen, 5(2),121-136.https://doi.org/10.15294/jdm.v5i2.3656.

Irmalis, A., Hadi, F., \& Muzakir, M. (2019). "Multivariate cointegration analysis on indonesia, malaysia, and singapore stock exchange". Proceedings of AICS-Social Sciences, 9, 63-71.

Jebran, K. (2018). Volatility spillover between stock and foreign exchange market of hongkong: evidence from subprime asian financial crisis. Journal of Asia Business Studies. https://doi.org/10.1108/JABS-01-2016-0003

Johansen, S. (1991). Estimation and hypothesis testing of cointegration vectors in gaussian vector autoregressive models. Econometrica. 59(6),1551-1580.

Kangina, N., Knyazev, A., Lepekhin, O., \& Shemyakin, A. (2016). Modeling joint distribution of national stock indices. Model Assisted Statistics and Applications, 11(1),1526.https://doi.org/10.3233/MAS-150350.

Lanouar,C.,Najah,A., \&Teulon, F.(2015). Socially responsibility investing and islamic fund : new perspective for portolio allocation. Reasearch in International Business and Finance, 351-361.

Mills, T.C. \& Mills, A.G. (1991). The international transmission of bond market movements, Bulletin of Economic Research , 43, 273 -82.

Natsir, K., Yusbardini, Y., \& Bangun, N. (2019). Analisis kausalitas antara ihsg, indeks dow jones industrial average dan nilai tukar rupiah/Us\$. Jurnal Muara Ilmu Ekonomi dan Bisnis, Vol. 3, No.2, pp.229. https://doi.org/10.24912/jmieb.v3i2.3398.

Robiyanto, R. (2017). The analysis of capital market integration in asean region by using the ogarch approach. Jurnal Keuangan Dan Perbankan, 22(2),169- 
175.https://doi.org/10.26905/jkdp.v21i2.1138.

Robiyanto, R. (2018). Capital market integration in some asean countries revisited. Jurnal Manajemen. 22(2),205.https://doi.org/10.24912/jm.v22i2.359.

Santoso, A., \& Setyawan, I. R. (2016). Long term relationship among the asian's stock market and Jakarta Composite Indices. Working Paper from Research Gate, January, 136. https://doi.org/10.13140/RG.2.1.4494.9520.

Sekaran, U., \& Bougie, R. (2016). Research methods for business, Seventh Edition. United Kingdom: John Wiley \& Sons. www.wileypluslearningspace.com

Simbolon, L., \& Purwanto. (2018). The influence of macroeconomic factors on stock price: the case of real estate and property companies. Research in Finance, 19-39. https://doi.org/10.1108/s0196-382120170000034010.

Suganda, T. R., \& Hariyono, A. R. (2018). The integration of asean-5 capital market after the Donald Trump Election. Jurnal Keuangan Dan Perbankan. 22(4), 656-669. https://doi.org/10.26905/jkdp.v22i4.1990.

Uchoa, P.(2018). "Krisis ekonomi 2008 dan keadaannya di sejumlah negara,termasuk Indonesia ,10 tahun kemudian". Retrieved October 12, 2019. https://www.bbc.com/indonesia/dunia45495304

Yossinilayanti, R. (2006), Dampak perubahan suku bunga SBI, suku bunga fed fund, laju inflasi dan nilai tukar rupiah terhadap transaksi investor asing dan domestik di bursa efek jakarta, Tesis MM UI, 1-209.

Zhan,F.(2019). Individualism, synchronized stock price movements, and stock market volatility International Journal of Managerial Finance, 15(3),371-403 https://doi.org/10.1108/IJMF 10-2018-0305

www.investing.com

www.investopedia.com 